\title{
HIGH EFFICIENCY AMORPHOUS AND MICROCRYSTALLINE SILICON BASED DOUBLE-JUNCTION SOLAR CELLS MADE WITH VERY-HIGH-FREQUENCY GLOW DISCHARGE
}

\author{
Phase I Final Technical Report \\ August 21, 2002 through May 20, 2003
}

A. Banerjee

United Solar Ovonic Corporation

Troy, Michigan

Prepared under DOE Grant No. DE-FG02-02ER83563 


\section{Table of Contents}

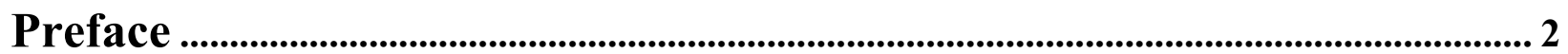

1. Objective ................................................................................................................................ 3

2. Background Information ............................................................................................. 3

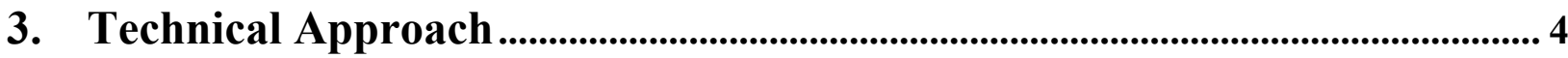

4. Progress and achievements made in the Phase $I$.......................................................... 4

4.1 Optimization of a-Si:H/ $\mu \mathrm{c}-\mathrm{Si}: \mathrm{H}$ double-junction solar cell 4

4.2 Stability of $\mu \mathrm{c}-\mathrm{Si}: \mathrm{H}$ single-junction and a-Si:H/ $\mu \mathrm{c}-\mathrm{Si}: \mathrm{H}$ double-junction solar cells 7

$\begin{array}{ll}4.3 & \text { Uniformity studies using large area cathode at VHF frequencies }\end{array}$

5. Summary of the Phase I achievements.......................................................................... 18

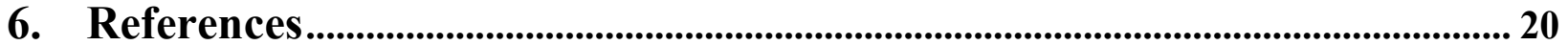




\section{Preface}

This annual Subcontract Report covers the work performed by United Solar Systems Corporation (now United Solar Ovonic Corporation) for the period from August 21, 2002 to May 20, 2003 under Department of Energy SBIR Grant No. DE-FG02-02ER83563. The following personnel participated in this research program.

A. Banerjee (Principal Investigator), E. Chen, G. Fischer, S. Guha, A. Mohsin, T. Nazmee, J. Noch, T. Palmer, D. Wolf, B. Yan, J. Yang, K. Younan, and G. Yue.

Collaboration with the Colorado School of Mines, University of North Carolina, and the National Renewable Energy Laboratory is acknowledged. 


\section{Objective}

The two main objectives of the Phase I research were: (1) to develop a modified very high frequency (MVHF) glow discharge technique to deposit high efficiency small-area a$\mathrm{Si}: \mathrm{H} / \mu \mathrm{c}-\mathrm{Si}: \mathrm{H}$ double-junction solar cells at high deposition rates and (2) study issues that affect film thickness uniformity for large area deposition.

\section{Background Information}

After more than two decades of extensive studies, thin film hydrogenated amorphous silicon (a-Si:H) solar cell technology has been successfully transferred to mass production. A 30 MW/year production line has produced solar panels at United Solar Ovonic Corporation since 2003 [1]. Compared to crystalline solar cells, a-Si:H has several advantages such as large area production, low cost, and lightweight. The best efficiency has been obtained using a spectrumsplitting triple-junction a-Si:H/a-SiGe:H/a-SiGe:H solar cell structure. The middle and bottom cells incorporate intermediate and narrow bandgap amorphous silicon-germanium alloy, a$\mathrm{SiGe}: \mathrm{H}$, respectively, to capture the intermediate and low energy photons. There are two major disadvantages of this approach. First is the high cost and toxicity of the germane, $\mathrm{GeH}_{4}$, gas that is required to deposit the a-SiGe:H material. The second is the poor device stability of the a$\mathrm{SiGe}: \mathrm{H}$ material under solar illumination. Consequently, the triple-junction structure suffers from significant light-induced degradation that results in reduced stable efficiency.

One potential solution is to replace the a-SiGe:H material with a thin film of hydrogenated microcrystalline silicon $(\mu \mathrm{c}-\mathrm{Si}: \mathrm{H})$. Since the first report in 1994 [2], significant progress has been made in the understanding of $\mu \mathrm{c}-\mathrm{Si}: \mathrm{H}$ material and solar cells [3-12]. Kaneka Corp. reported an initial cell efficiency of $14.5 \%$ and an initial module efficiency of $12.33 \%$ [3] using an a-Si:H/ $\mu \mathrm{c}-\mathrm{Si}: \mathrm{H}$ double-junction solar cell structure. The efficiency values are close to those obtained using the all-amorphous a-Si:H/a-SiGe:H/a-SiGe:H triple-junction solar cells [4,5]. Due to the low light-induced degradation [2,6] and elimination of $\mathrm{GeH}_{4}$ gas in the deposition process, the a-Si:H/ $\mu \mathrm{c}-\mathrm{Si}: \mathrm{H}$ double-junction structure offers a powerful alternative.

Currently, $\mu \mathrm{c}-\mathrm{Si}: \mathrm{H}$ based solar cells are still mainly in the research and development stage. Before transferring this technology to mass production, several issues must be addressed. First, the bandgap of $\mu \mathrm{c}-\mathrm{Si}: \mathrm{H}$ is lower than a-SiGe:H used in our triple-junction solar cells. Therefore, the long wavelength response of $\mu \mathrm{c}-\mathrm{Si}: \mathrm{H}$ solar cell is superior to a-SiGe:H solar cell. However, due to indirect nature of the bandgap, the maximum absorption coefficient is lower in $\mu \mathrm{c}-\mathrm{Si}: \mathrm{H}$ than in a-SiGe:H. In order to obtain high short-circuit current density $\left(\mathrm{J}_{\mathrm{sc}}\right)$, a relatively thick $\mu \mathrm{c}-\mathrm{Si}: \mathrm{H}$ intrinsic layer $(>1 \mu \mathrm{m})$ is required. This requirement necessitates the adoption of a high deposition rate in order to make it attractive for commercial exploitation. One problem of using a high deposition rate is that the quality of the $\mu \mathrm{c}-\mathrm{Si}: \mathrm{H}$ suffers. The reduced quality, in turn, affects the device efficiency. Therefore, the main objective for this project is to develop a high rate deposition technique for high performance $\mu \mathrm{c}-\mathrm{Si}: \mathrm{H}$ thin film solar cells and evaluate the possibility to use $\mu \mathrm{c}-\mathrm{Si}: \mathrm{H}$ in an a-Si:H/ $\mu \mathrm{c}-\mathrm{Si}: \mathrm{H}$ double-junction structure. 


\section{Technical Approach}

Very high frequency (VHF) glow discharge $[2,12]$ and RF glow discharge at high pressure depleting regime (RF-HPD) [8-11] are the two successful methods for high rate $\mu \mathrm{c}-\mathrm{Si}: \mathrm{H}$ deposition. We have used a MVHF glow discharge to deposit a-Si:H and a-SiGe:H alloy solar cells and achieved good results [13]. In the project, we have used the MVHF technique for high rate $\mu \mathrm{c}-\mathrm{Si}: \mathrm{H}$ deposition. We optimized all the deposition parameters to improve the cell efficiency. At the same time, we used a large area VHF system to optimize the uniformity of a$\mathrm{Si}: \mathrm{H}$ and $\mu \mathrm{c}-\mathrm{Si}: \mathrm{H}$ films on large-area substrate.

\section{Progress and achievements made in Phase I}

We used a multi-chamber system with three RF glow discharge chambers and one MVHF glow discharge chamber to deposit $\mu \mathrm{c}-\mathrm{Si}: \mathrm{H}$ single-junction and a-Si:H/ $/ \mathrm{c}-\mathrm{Si}: \mathrm{H}$ doublejunction solar cells. The VHF excitation frequency was 60-80 MHz. $\mu \mathrm{c}-\mathrm{Si}: \mathrm{H}$ single-junction and a-Si:H/ $\mu \mathrm{c}-\mathrm{Si}: \mathrm{H}$ double-junction solar cells were deposited on specular stainless steel (ss) and $\mathrm{Ag} / \mathrm{ZnO}$ back reflector coated ss substrates. Special samples were deposited on various substrates for materials characterization. We optimized plasma parameters, such as $\mathrm{H}_{2}$ dilution, substrate temperature, pressure, VHF power, and gas flow rates. We designed various cell structures encompassing different microcrystalline content, different thicknesses, and different interfaces. We characterized material properties using secondary ion mass spectroscopy (SIMS), Raman, X-ray diffraction and small angle X-ray scattering measurements. The materials properties and their dependence on plasma parameters provided feedback for optimization of the solar cell structure and device efficiency. We conducted stability studies of ambient degradation attributable to post-deposition diffusion of impurities and degradation against prolonged light exposure. The major achievements of Phase I are summarized below.

\subsection{Optimization of a-Si:H/ $\mu \mathrm{c}-\mathrm{Si}: \mathrm{H}$ double-junction solar cell}

An initial total-area efficiency of $11.5 \%$ (active-area efficiency 12.3\%) has been achieved using a-Si:H/ $\mu \mathrm{c}-\mathrm{Si}: \mathrm{H}$ double-junction structure deposited on $\mathrm{Ag} / \mathrm{ZnO}$ coated back reflector. Figure 1 shows (a) the J-V characteristics and (b) quantum efficiency of the cell with the highest initial efficiency. The quantum efficiency curve (Fig. 1 (b)) clearly demonstrates the enhanced long wavelength response attributable to the narrow optical gap of the $\mu \mathrm{c}-\mathrm{Si}: \mathrm{H}$ intrinsic layer and light-trapping effect of the $\mathrm{Ag} / \mathrm{ZnO}$ back reflector. The total current of $23.9 \mathrm{~mA} / \mathrm{cm}^{2}$ is significantly greater than that of an a-Si:H/a-SiGe:H double-junction solar cell. For a doublejunction solar cell, the AM1.5 FF is dominated by the FF of the cell with lower short-circuit current density. Figure 2 shows the J-V characteristics under blue and red light. Under white light, the top cell and the bottom cell have very matched current density as shown in Fig. 1 (b) and the FF is 0.744 . Under blue light, the bottom cell is weakly absorbing and the $\mathrm{J}_{\mathrm{sc}}$ is severely limited by the bottom cell. The blue FF reflects the quality of the weakly-absorbing bottom cell; a value of 0.822 demonstrates the high quality of the $\mu \mathrm{c}-\mathrm{Si}: \mathrm{H}$ intrinsic layer in the bottom cell. Under red light, the FF is limited by the a-Si:H top cell, and the value of 0.747 is consistent with normally obtained in high quality a-Si:H single-junction solar cells under reduced light intensity. It should be noted that the FF under the reduced intensity colored light (Figs. 2 (a) and 2 (b)) is 

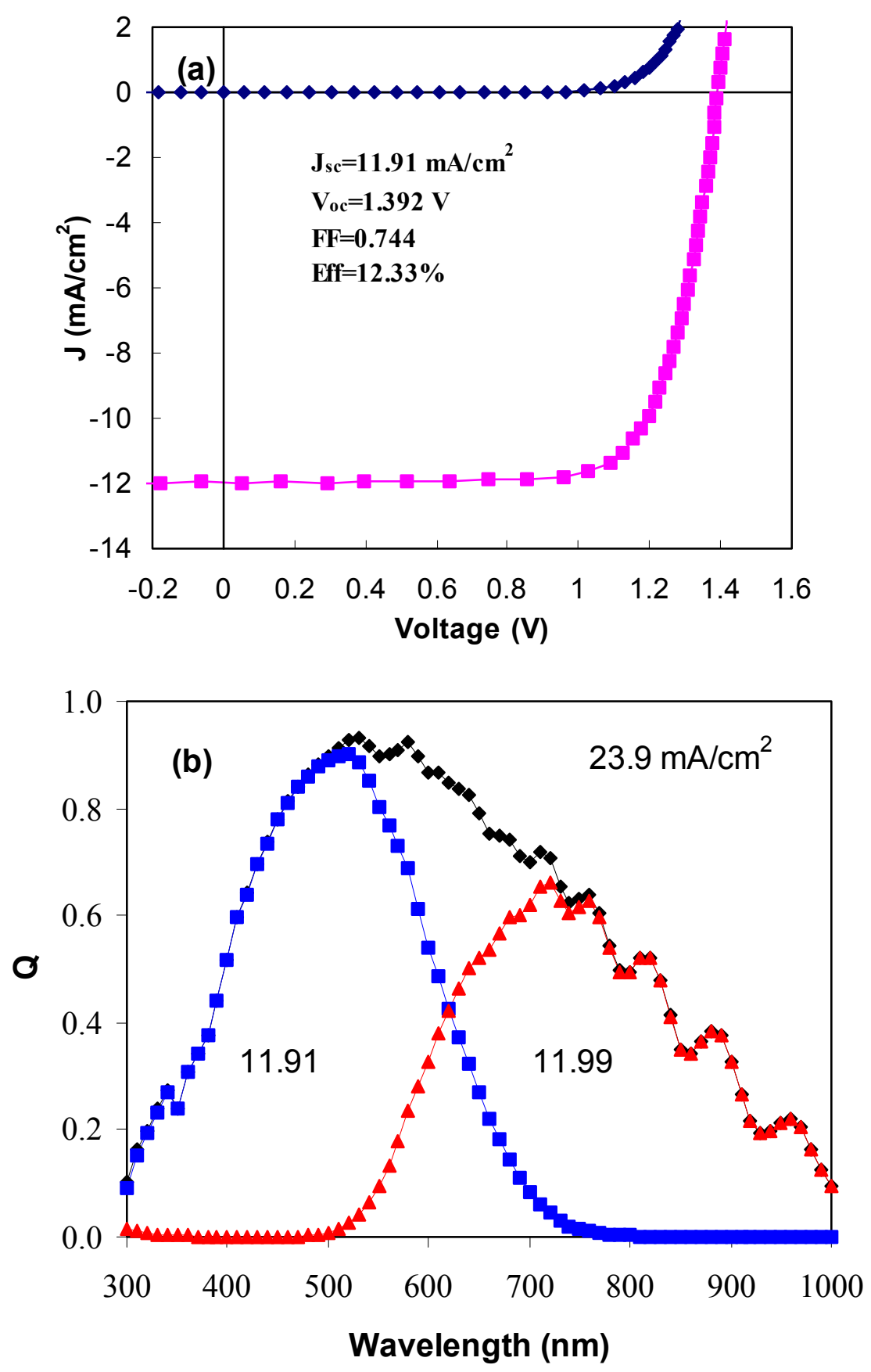

Figure 1. (a) J-V characteristics and (b) quantum efficiency of the best MVHF deposited a$\mathrm{Si}: \mathrm{H} / \mu \mathrm{c}-\mathrm{Si}: \mathrm{H}$ double-junction solar cell at high deposition rates. The deposition time for the intrinsic $\mu \mathrm{c}-\mathrm{Si}: \mathrm{H}$ layer in the bottom cell is $\sim 50$ minutes. 

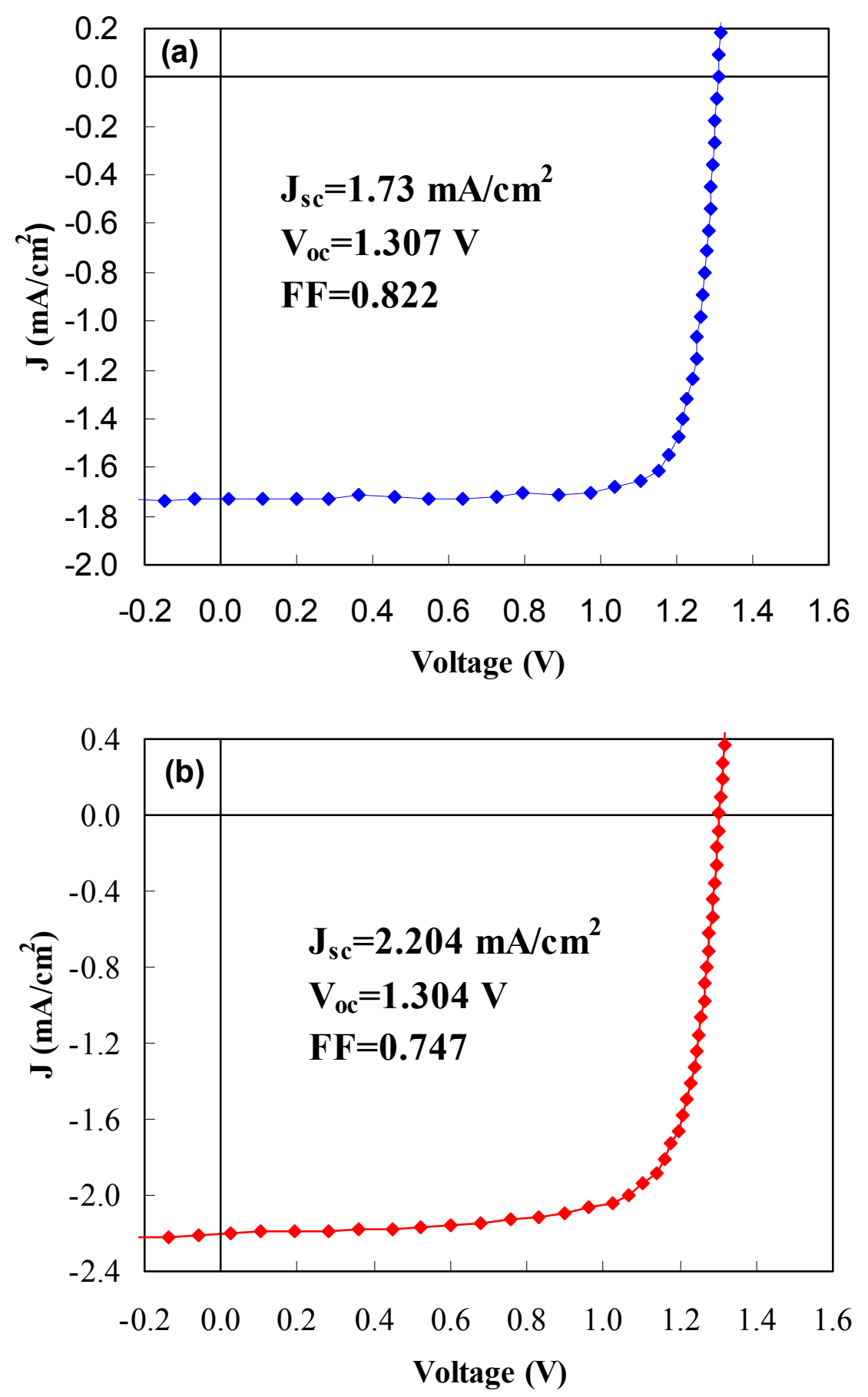

Figure 2. J-V characteristics of the cell shown in Fig. 1 under AM1.5 illumination with (a) a $585 \mathrm{~nm}$ short-pass filter and (b) a $610 \mathrm{~nm}$ long-pass filter. 
higher than under AM1.5 illumination due to the light intensity dependence and bias effect in the cell.

The intrinsic a-Si:H layer in the top cell and the $\mu \mathrm{c}-\mathrm{Si}: \mathrm{H}$ intrinsic layer in the bottom cell in the a-Si:H/ $\mu \mathrm{c}-\mathrm{Si}: \mathrm{H}$ double-junction structure as shown in Fig. 1 were deposited for $7 \mathrm{~min}$. and 50 minutes, respectively. The results led us to conclude that the deposition time, rather than the deposition rate, determines the attractiveness of the process for the production environment. The important requirements for the bottom cell are (1) it has high quality, (2) it generates adequate current density, and (3) it is deposited in a relatively short time. This strategy opens up the possibility of using thin layers of the $\mu \mathrm{c}-\mathrm{Si}: \mathrm{H}$ material that results in high device FF. This approach also helps in improving the stability of the double-junction device. We made the assumption that a deposition time of $30 \mathrm{~min}$ for the $\mu \mathrm{c}-\mathrm{Si}: \mathrm{H}$ layer in the bottom cell would make the MVHF technique attractive for commercial use. A similar analysis has been published by Shah et al. [12].

For designed cell thickness $\sim 1.0 \mu \mathrm{m}$ and deposition time $\sim 30 \mathrm{~min}$., the deposition rate is $\sim 5 \AA / \mathrm{s}$. It is clear that the deposition time (50min) of the bottom cell in Fig. 1 is needed to be short. We carried out cell optimization studies on the bottom cell that included reducing the bottom cell deposition time, improving material quality, increasing deposition rate and reducing the thickness of the bottom cell. Table I lists the results of a-Si:H/ $\mu$ c-Si:H double-junction solar cells made with different bottom cells times. By reducing the bottom cell deposition time to 30 minutes, we achieved an initial active-area of $11.35 \%$ (total-area efficiency of $10.6 \%$ ). Although the cell initial efficiency is lower for the cell with 35 and 30 minutes of bottom cell deposition time, they have better stable efficiency. The stability issues are described in the next section.

Table I. J-V characteristics of a-Si:H/ $\mu \mathrm{c}-\mathrm{Si}: \mathrm{H}$ double-junction solar cells with different bottom cell deposition time. The underlined data indicate the limiting current.

\begin{tabular}{|c|c|c|c|c|c|c|}
\hline \multirow{2}{*}{$\begin{array}{c}\text { Sample } \\
\text { No }\end{array}$} & \multirow{2}{*}{$\begin{array}{c}\text { Bottom time } \\
(\mathrm{min} .)\end{array}$} & \multirow{2}{*}{$\begin{array}{c}\text { Efficiency } \\
(\%)\end{array}$} & \multicolumn{2}{|c|}{ Jsc $\left(\mathrm{mA} / \mathrm{cm}^{2}\right)$} & \multirow{2}{*}{$\begin{array}{l}\mathrm{V}_{\text {oc }} \\
(\mathrm{V})\end{array}$} & FF \\
\cline { 4 - 5 } & & & top & bottom & & \\
\hline 11569 & 60 & 12.04 & 12.09 & $\underline{12.07}$ & 1.359 & 0.734 \\
\hline 11635 & 50 & 12.33 & $\underline{11.91}$ & 11.99 & 1.392 & 0.744 \\
\hline 11797 & 35 & 11.34 & 11.77 & $\underline{10.73}$ & 1.385 & 0.763 \\
\hline 11835 & 30 & 11.35 & 11.19 & $\underline{11.10}$ & 1.406 & 0.727 \\
\hline
\end{tabular}

\subsection{Stability of $\mu \mathrm{c}-\mathrm{Si}: \mathrm{H}$ single-junction and a-Si:H/ $\mu \mathrm{c}-\mathrm{Si}: \mathrm{H}$ double-junction solar cells}

One of the advantages of $\mu \mathrm{c}-\mathrm{Si}: \mathrm{H}$ over a-Si:H and a-SiGe:H is that optimized $\mu \mathrm{c}-\mathrm{Si}: \mathrm{H}$ solar cells are stable against prolonged light soaking. However, fabrication of stable $\mu \mathrm{c}-\mathrm{Si}: \mathrm{H}$ solar cells require the optimization of not only the $\mu \mathrm{c}-\mathrm{Si}: \mathrm{H}$ material but also the device design. Early studies showed that $\mu \mathrm{c}-\mathrm{Si}: \mathrm{H}$ films are susceptible to oxidation after deposition [14]. Significant increase in the oxygen related infrared absorption was observed in sputter-deposited $\mu \mathrm{c}-\mathrm{Si}: \mathrm{H}$ films. A similar phenomenon was found in our high rate MVHF $\mu \mathrm{c}-\mathrm{Si}: \mathrm{H}$ solar cells deposited under certain unoptimized conditions [15]. The solar cell performance degraded 
without intentional light soaking, a phenomenon called ambient degradation. An example of such ambient degradation is shown in Fig. 3, where the J-V characteristics and quantum efficiency are shown for the initial state and after one month of storage under ambient condition. The $\mathrm{J}_{\mathrm{sc}}$ decreased from $24.48 \mathrm{~mA} / \mathrm{cm}^{2}$ to $19.97 \mathrm{~mA} / \mathrm{cm}^{2}, \mathrm{~V}_{\text {oc }}$ from $0.433 \mathrm{~V}$ to $0.400 \mathrm{~V}$, FF from 0.559 to 0.535 , and the efficiency from $5.9 \%$ to $4.3 \%$. The loss of current occurs mainly in the long wavelength region, as shown in Fig. 3 (b). This ambient degradation saturated after a few weeks. Subsequent thermal annealing did not recover the cell performance, but produced further degradation.

In order to find out the origin of the ambient degradation, five solar cells were made using the same recipe. On one cell (No. 10931), ITO was deposited immediately after the deposition of the nip structure. The J-V characteristics and quantum efficiency were measured on the same day. Then, the sample was kept in air at room temperature and measured at different times. The other four samples were kept for seven days under various conditions, as listed in Table II, before the ITO deposition. The J-V characteristics and quantum efficiency of the four cells were measured after the ITO deposition. The results show that: i) the degradation is very small if the sample was maintained in dry $\mathrm{N}_{2}$ environment (compare No. 10928 and fresh No. 10931); ii) the degradation is significant if the sample stays in air at room temperature (compare No. 10928 and No. 10929); iii) the degradation is more significant at a high temperature than at room temperature (compare No. 10929 and No. 10930); iv) the degradation is lower in dry air and a low temperature (compare No. 10929 and No. 10932); and v) ITO causes more degradation (compare No. 10929 and No. 10931). In addition, we found that the sample with ITO also showed a large degradation even in dry $\mathrm{N}_{2}$ environment (results not shown), which indicates that the sample with ITO degrades due to the diffusion of oxygen from ITO. From these comparisons, we believe that the ambient degradation is due to the oxygen diffusion into the solar cells after the samples were removed from the chamber. It has been reported that the $\mu \mathrm{c}-\mathrm{Si}: H$ films deposited by sputtering [14] and hot-wire CVD [16] exhibit similar postdeposition oxygen diffusion. Goerlitzer et al. [17] reported that impurities can diffuse into the $\mu \mathrm{c}-\mathrm{Si}: \mathrm{H}$ films deposited with VHF at high powers. They found a strong (220) preferential orientation in the samples with the oxygen diffusion and suggested [17] that the well-defined orientation perpendicular to the substrate could favor the formation of voids and cracks, which yields high porosity in the $\mu \mathrm{c}-\mathrm{Si}: \mathrm{H}$. However, although some of our samples indeed show (220)

Table II. $\mathrm{J}_{\mathrm{sc}}$ of $\mu \mathrm{c}-\mathrm{Si}: \mathrm{H}$ solar cells made with the same recipe, but kept at different conditions before ITO deposition.

\begin{tabular}{|c|c|c|c|c|c|}
\hline Sample No. & Environment & \multirow{2}{*}{ Temperature } & \multicolumn{2}{|c|}{$\mathrm{J}_{\mathrm{sc}}\left(\mathrm{mA} / \mathrm{cm}^{2}\right)$} & Comments \\
\cline { 4 - 6 } & & & initial & 7 days & \\
\hline 10928 & dry $\mathrm{N}_{2}$ & room & & 21.17 & ITO after 7 days \\
\hline 10929 & air & room & & 18.60 & ITO after 7 days \\
\hline 10930 & air & $100^{\circ} \mathrm{C}$ & & 15.37 & ITO after 7 days \\
\hline 10931 & air & room & $\mathbf{2 1 . 4 2}$ & $\mathbf{1 6 . 4 0}$ & ITO immediately \\
\hline 10932 & dry Air & $-16^{\circ} \mathrm{C}$ & & 20.59 & ITO after 7 days \\
\hline
\end{tabular}



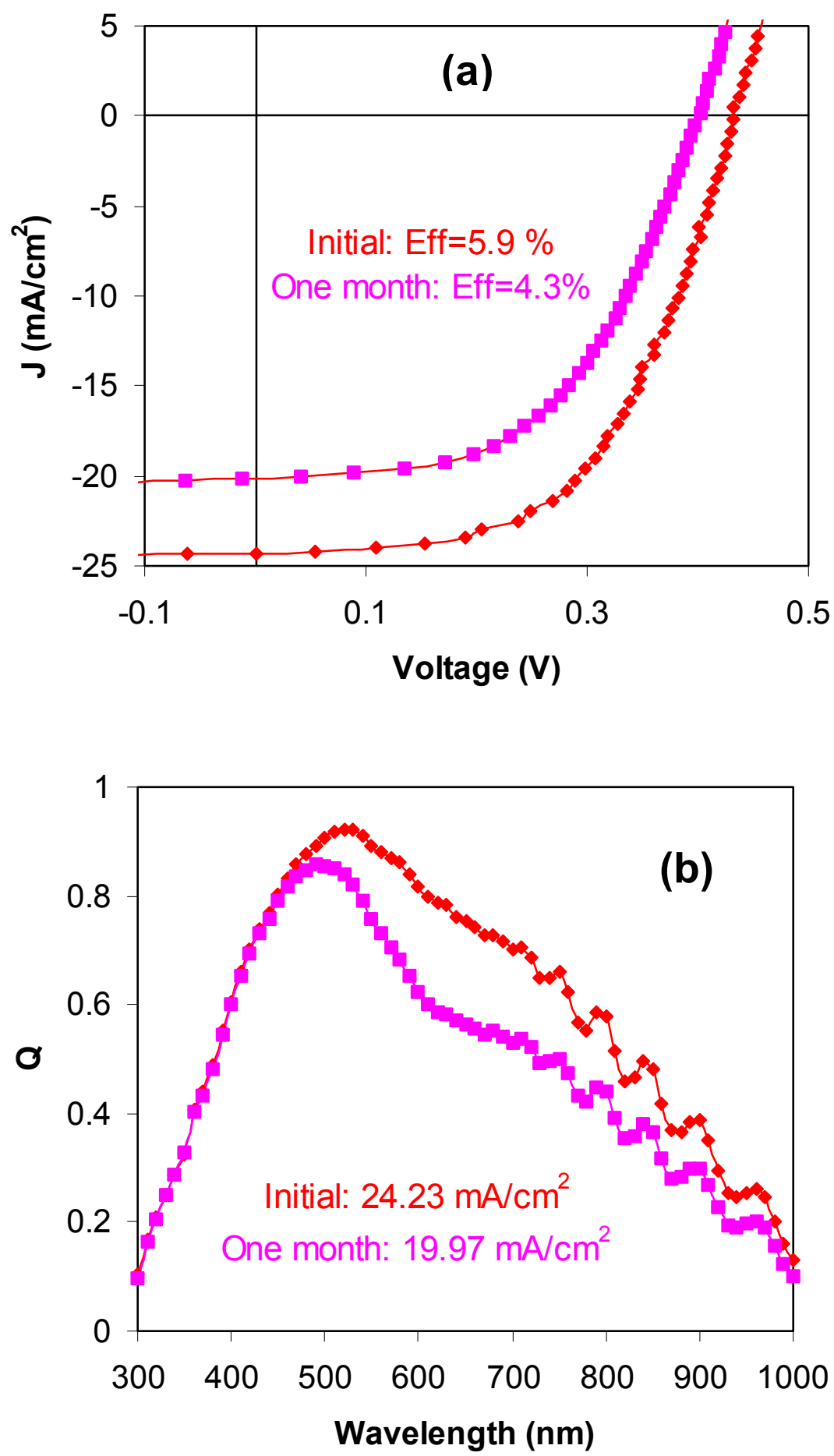

Figure 3. (a) J-V characteristics and (b) quantum efficiency of a $\mu \mathrm{c}-\mathrm{Si}: \mathrm{H}$ cell in its initial state and after 30 days in ambient without intentional light soaking. 
preferential orientation, we do not believe that (220) preferential orientation is the only reason for ambient degradation since our low rate RF deposited $\mu \mathrm{c}-\mathrm{Si}: \mathrm{H}$ solar cells also show a (220) preferential orientation, but are stable under the ambient condition.

From the above studies, we believe that the ambient degradation is due to post-oxygen diffusion into the solar cell. Therefore, one could easily speculate that the post-oxygen diffusion would not influence the performance of a-Si:H/ $\mu \mathrm{c}-\mathrm{Si}: \mathrm{H}$ double-junction solar cells since the a$\mathrm{Si}: \mathrm{H}$ top cell acts as a cap to block the oxygen diffusion. Experimentally, we still observe the ambient degradation of the double-junction cells that has a top cell thickness $\sim 3500 \AA$ for current matching between the top and bottom cells. Figure 4 shows the (a) J-V characteristics and (b) quantum efficiency of an a-Si:H/ $\mu \mathrm{c}-\mathrm{Si}: \mathrm{H}$ solar cell, where the bottom cell was made with a recipe that produces unstable $\mu \mathrm{c}-\mathrm{Si}$ :H single-junction cells. As shown in Fig. 4 (b) and Table III, the $\mu \mathrm{c}-\mathrm{Si}: \mathrm{H}$ bottom cell degraded. The $\mathrm{J}_{\mathrm{sc}}$ of the bottom cell of device No. 10948 dropped from $12.92 \mathrm{~mA} / \mathrm{cm}^{2}$ to $11.29 \mathrm{~mA} / \mathrm{cm}^{2}$ after the sample was kept under ambient condition for five months, but it did not change after 150 hours of light soaking (not shown). SIMS analysis showed that impurities indeed diffused into the $\mu \mathrm{c}-\mathrm{Si}: \mathrm{H}$ layer through an a-Si:H top layer (not shown). Oxygen content reached to $>10^{20}$ atoms $/ \mathrm{cm}^{3}$ in the bottom $\mu \mathrm{c}-\mathrm{Si}$ :H layer, but remained at $10^{19}$ atoms $/ \mathrm{cm}^{3}$ in the top a-Si:H layer. This results suggests that the unoptimized $\mu \mathrm{c}-\mathrm{Si}: \mathrm{H}$ layer is porous and causes micro-cracks in the top a-Si:H layer (the top cell) and provides the channel for impurity diffusion.

We have optimized the plasma conditions and found some plasma regimes under which the $\mu \mathrm{c}-\mathrm{Si}: \mathrm{H}$ solar cells do not show any ambient degradation. Figure 5 shows a plot of $\mathrm{J}_{\mathrm{sc}}$ as a function of time for two solar cells. Cell 10976 deposited under an unoptimized condition shows a large degradation, but the other (No. 10973) deposited under optimized conditions does not show any $J_{\mathrm{sc}}$ degradation after 5 months, and only small reductions in $\mathrm{V}_{\mathrm{oc}}$ and $\mathrm{FF}$ (not shown). We then made a-Si:H/ $\mu \mathrm{c}-\mathrm{Si}: \mathrm{H}$ double-junction solar cells with the bottom cell that does not show the ambient degradation, such as in cell 12033 shown in Table III.

Optimized $\mu \mathrm{c}-\mathrm{Si}: \mathrm{H}$ solar cells have better stability against light soaking than a-Si:H and a-SiGe:H solar cells. However, in an a-Si:H/ $\mu \mathrm{c}-\mathrm{Si}: \mathrm{H}$ structure, the a-Si:H top cell is typically $>3000 \AA$ to provide enough current to match the current of the $\mu \mathrm{c}-\mathrm{Si}: \mathrm{H}$ bottom cell. Such a thick a-Si:H solar cell usually shows substantial degradation, $20-40 \%$, after light soaking. Therefore,

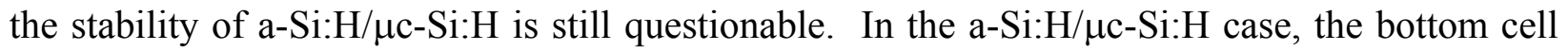
has better stability than the top cell, thus a bottom cell limited a-Si:H/ $\mu \mathrm{c}-\mathrm{Si}: \mathrm{H}$ double-junction

Table III. Summary of a-Si:H/ $\mu$ c-Si:H double-junction solar cells made with unoptimized $\mu c-$ $\mathrm{Si}: \mathrm{H}$ bottom cell (10948) and optimized $\mu \mathrm{c}-\mathrm{Si}: \mathrm{H}$ bottom cell at various states.

\begin{tabular}{|c|c|c|c|c|c|c|c|}
\hline \multirow{2}{*}{$\begin{array}{c}\text { Sample } \\
\text { No. }\end{array}$} & \multirow{2}{*}{$\begin{array}{l}\text { Eff. } \\
(\%)\end{array}$} & \multirow{2}{*}{$\begin{array}{c}\mathrm{J}_{\mathrm{sc}} \\
\left(\mathrm{mA} / \mathrm{cm}^{2}\right)\end{array}$} & \multirow{2}{*}{$\begin{array}{l}V_{o c} \\
(V)\end{array}$} & \multirow[t]{2}{*}{ FF } & \multicolumn{2}{|c|}{$\mathrm{Q}\left(\mathrm{mA} / \mathrm{cm}^{2}\right)$} & \multirow[t]{2}{*}{ States } \\
\hline & & & & & top & bottom & \\
\hline \multirow[t]{3}{*}{10948} & 11.7 & 12.86 & 1.372 & 0.661 & 12.86 & 12.92 & Initial \\
\hline & 10.6 & 11.44 & 1.365 & 0.676 & 12.73 & 11.44 & 11 days in ambient \\
\hline & 10.4 & 11.29 & 1.363 & 0.677 & 12.54 & 11.29 & 5 months in ambient \\
\hline \multirow[t]{2}{*}{12033} & 11.47 & 11.44 & 1.406 & 0.713 & 11.44 & 12.48 & Initial \\
\hline & 11.26 & 11.25 & 1.408 & 0.711 & 11.25 & 12.41 & 15 days in ambient \\
\hline
\end{tabular}



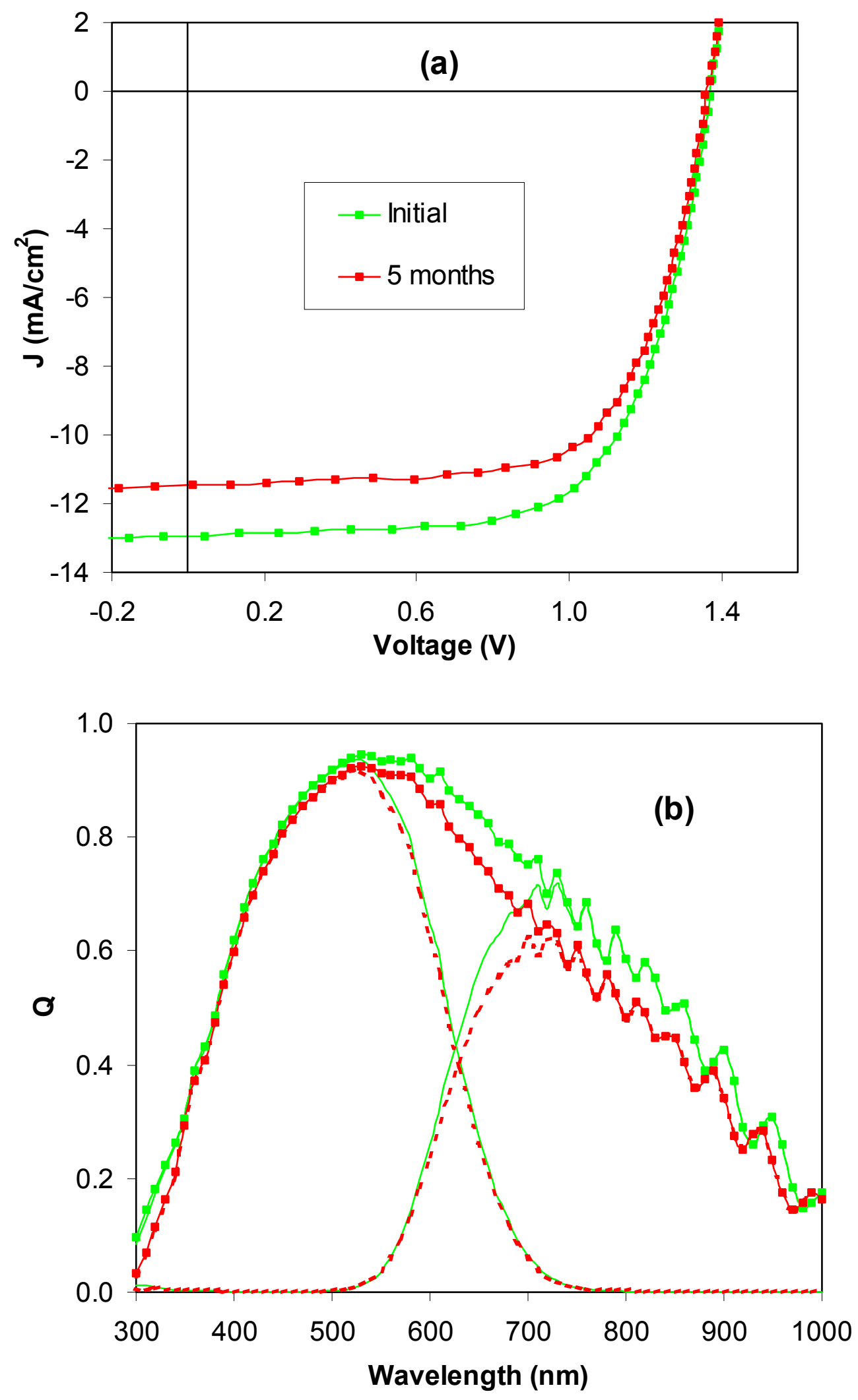

Figure 4. (a) J-V characteristics and (b) quantum efficiency of an a-Si:H/ $\mu \mathrm{c}-\mathrm{Si}: \mathrm{H}$ doublejunction cell measured on the same day of deposition (green) and after five months under ambient condition (red). 


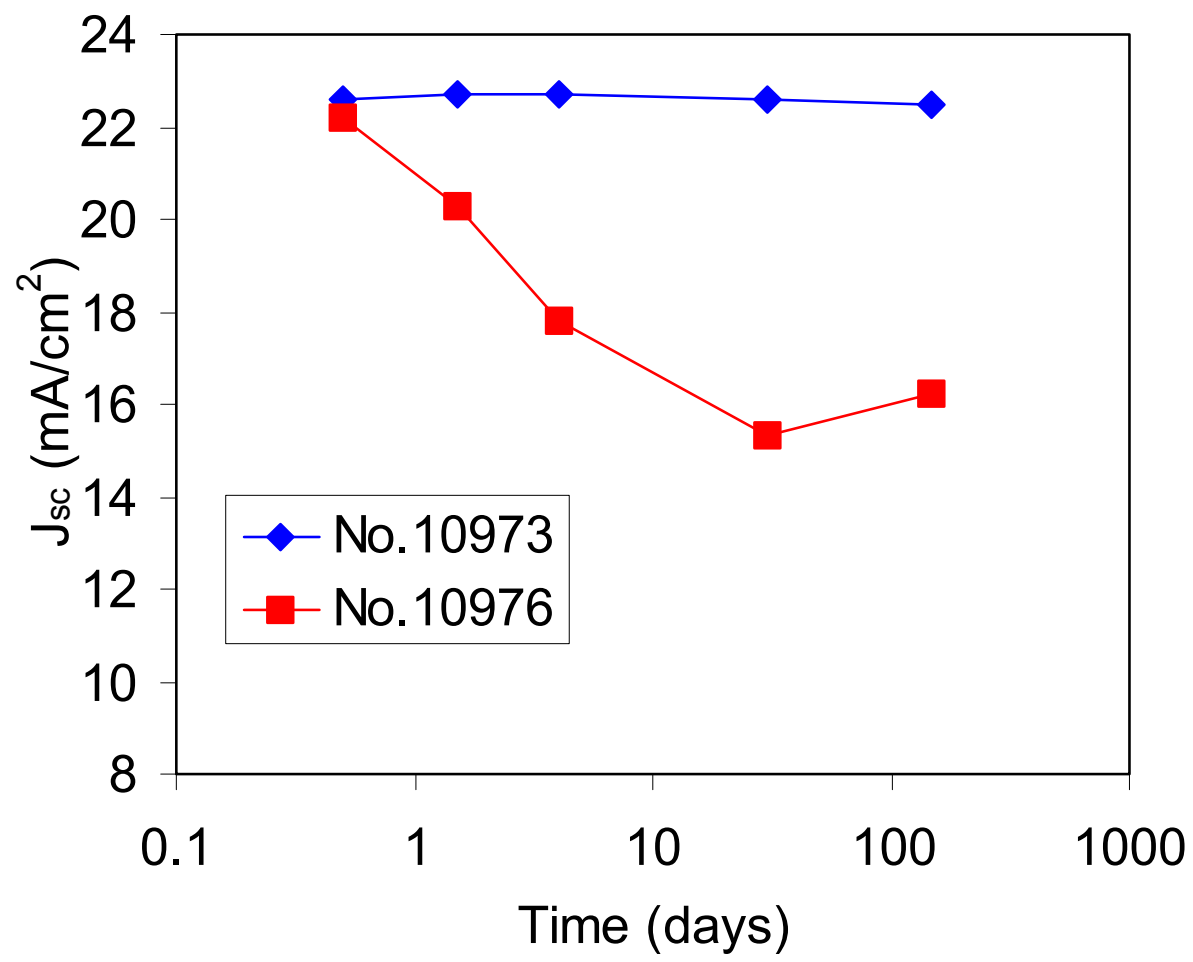

Figure 5. $\mathrm{J}_{\mathrm{sc}}$ as a function of time stored under ambient condition without intentional light soaking for $\mu \mathrm{c}-\mathrm{Si}: \mathrm{H}$ single-junction cells made under optimized condition (10973) and unoptimized condition (10976). 
cell should have better stability than one limited by the top cell. To confirm this hypothesis, we did light-soaking studies using a-Si:H/ $\mu \mathrm{c}-\mathrm{Si}: \mathrm{H}$ double-junction cells with different current mismatches. The data are summarized in Table IV. For comparison, an a-Si:H/a-Si:H cell was used as a reference. The MVHF high-rate cell 11635 had the best initial efficiency of $12.33 \%$. This cell had a matched current density between the top and bottom cells at the initial state. After light soak, the cell degraded $18.1 \%$ and reached a stable efficiency of $10.10 \%$. Another cell (11834) had a large current mismatch, with the bottom cell being the current limiter. Though the initial efficiency is lower than 11635 , this cell only degraded only $7.8 \%$ and reached a stable efficiency of $10.42 \%$. The stable efficiency is even better than the one with the highest initial efficiency of $12.33 \%$.

An example of the kinetics of light soaking for two cells in Table IV with different current mismatches is shown in Fig. 6. The top graph shows that the bottom cell limited device (sample 11568) degraded $\sim 11.9 \%$; the current-matched one (sample 11570 ) degraded $\sim 21 \%$. Sample 11570 exhibited degradation in $\mathrm{J}_{\mathrm{sc}}$ of $6.1 \%$. Further, the cell 11568 exhibited saturation after $\sim 20$ hours but the cell 11570 needed $\sim 100$ hours to reach a stable state. This result shows that a bottom cell limited a-Si:H/ $\mu \mathrm{c}-\mathrm{Si}: \mathrm{H}$ double-junction structure has superior stability compared to a top cell limited or current matched one. The lower graph in Fig. 6 shows a plot of the initial and stable efficiency versus the current mismatch defined as $J_{\mathrm{sc}}($ top $) / J_{\mathrm{sc}}$ (bottom) for a$\mathrm{Si}: \mathrm{H} / \mu \mathrm{c}-\mathrm{Si}: \mathrm{H}$ double-junction structures with similar top cell thicknesses.

Table IV. Stability of different a-Si:H/ $\mu \mathrm{c}-\mathrm{Si}: \mathrm{H}$ double-junction solar cells made using RF at a low rate and using MVHF at a high rate. For reference, a low rate RF a-Si:H/a-Si:H double-junction cells is also shown. The underlined $\mathrm{J}_{\mathrm{sc}}$ 's are limiting current densities.

\begin{tabular}{|c|c|c|c|c|c|c|}
\hline \multirow{2}{*}{$\begin{array}{c}\text { Sample } \\
\text { No. }\end{array}$} & \multirow[t]{2}{*}{ State } & \multirow{2}{*}{$\begin{array}{c}\text { Efficiency } \\
(\%)\end{array}$} & \multicolumn{2}{|c|}{$\mathrm{J}_{\mathrm{sc}}\left(\mathrm{mA} / \mathrm{cm}^{2}\right)$} & \multirow{2}{*}{$\begin{array}{l}\mathrm{V}_{\mathrm{oc}} \\
(\mathrm{V})\end{array}$} & \multirow[t]{2}{*}{$\mathrm{FF}$} \\
\hline & & & Top & Bott. & & \\
\hline \multirow{3}{*}{$\begin{array}{c}\text { MVHF } \\
11635\end{array}$} & Initial & 12.33 & 11.91 & 11.99 & 1.392 & 0.744 \\
\hline & Stable & 10.10 & 11.38 & 11.83 & 1.351 & 0.657 \\
\hline & Degradation & $18.1 \%$ & $4.7 \%$ & $1.4 \%$ & $2.9 \%$ & $11.6 \%$ \\
\hline \multirow{3}{*}{$\begin{array}{c}\text { MVHF } \\
11570\end{array}$} & Initial & 11.76 & 12.09 & $\underline{12.07}$ & 1.359 & 0.717 \\
\hline & Stable & 9.30 & 11.37 & 12.11 & 1.323 & 0.618 \\
\hline & Degradation & $20.9 \%$ & $6.0 \%$ & $-0.3 \%$ & $2.6 \%$ & $13.8 \%$ \\
\hline \multirow{3}{*}{$\begin{array}{c}\text { MVHF } \\
11568\end{array}$} & Initial & 11.62 & 12.15 & 10.96 & 1.386 & 0.765 \\
\hline & Stable & 10.24 & 11.47 & 10.89 & 1.351 & 0.696 \\
\hline & Degradation & $11.9 \%$ & $6.1 \%$ & $0.6 \%$ & $2.5 \%$ & $9.0 \%$ \\
\hline \multirow{3}{*}{$\begin{array}{c}\text { MVHF } \\
11834\end{array}$} & Initial & 11.30 & 12.09 & 10.77 & 1.404 & 0.747 \\
\hline & Stable & 10.42 & 11.70 & 10.67 & 1.374 & 0.711 \\
\hline & Degradation & $7.8 \%$ & $3.2 \%$ & $0.9 \%$ & $2.1 \%$ & $4.8 \%$ \\
\hline \multirow{3}{*}{$\begin{array}{c}\text { MVHF } \\
11835\end{array}$} & Initial & 11.35 & 11.19 & 11.10 & 1.406 & 0.727 \\
\hline & Stable & 10.42 & 10.85 & 10.96 & 1.378 & 0.697 \\
\hline & Degradation & $8.2 \%$ & $3.0 \%$ & $1.3 \%$ & $2.0 \%$ & $4.1 \%$ \\
\hline \multirow{3}{*}{$\begin{array}{c}\text { a-Si/a-Si } \\
\text { RF } \\
7361\end{array}$} & Initial & 11.66 & 8.13 & 8.15 & 1.975 & 0.726 \\
\hline & Stable & 9.70 & 7.88 & 7.99 & 1.914 & 0.643 \\
\hline & Degradation & $16.8 \%$ & $3.1 \%$ & $2.0 \%$ & $3.1 \%$ & $11.4 \%$ \\
\hline
\end{tabular}



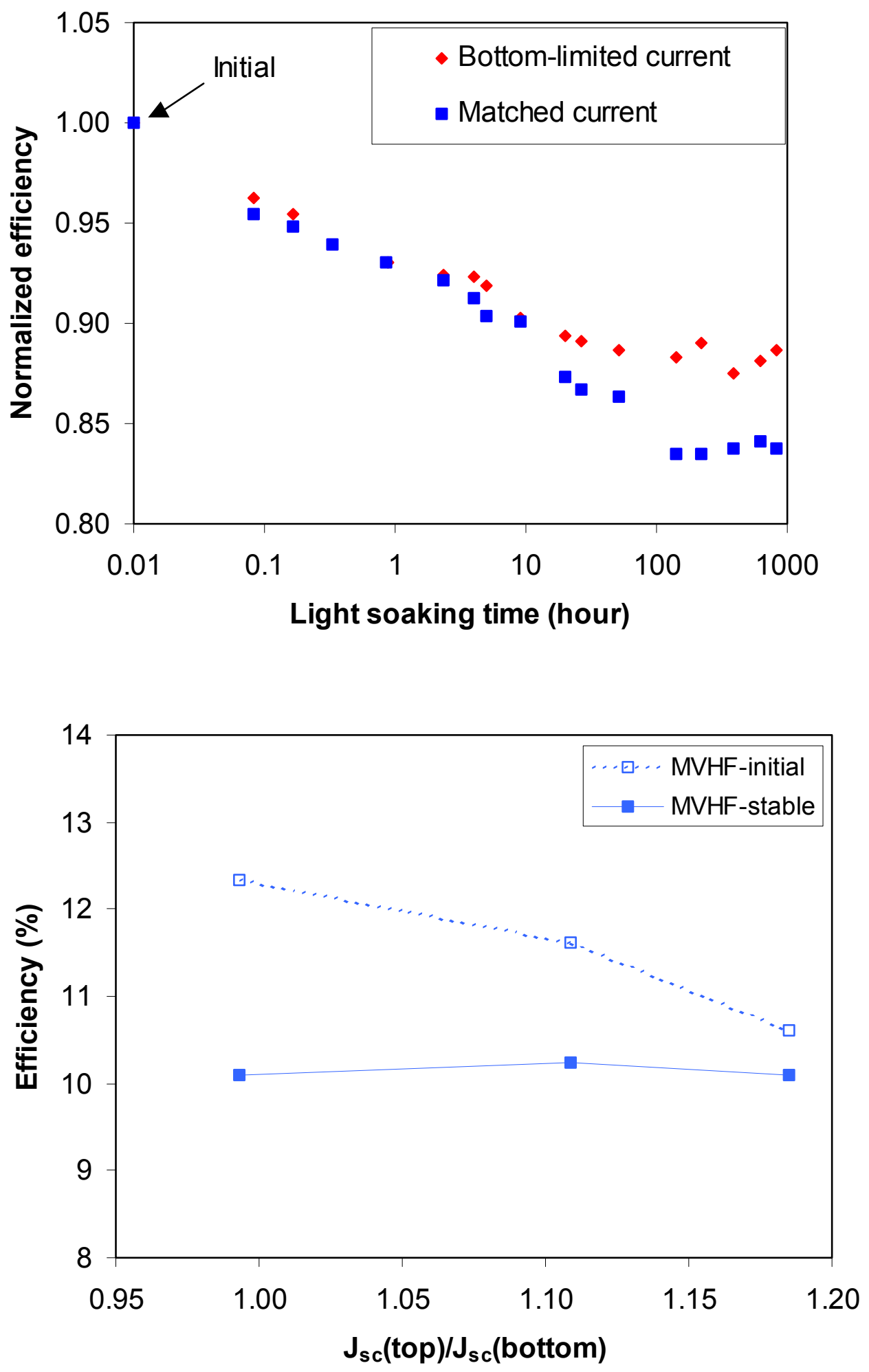

Figure 6. (top) Kinetics of a-Si:H/ $\mu \mathrm{c}-\mathrm{Si}: \mathrm{H}$ double-junction solar cells with matched current and bottom cell limited current mismatches, and (bottom) initial and stable efficiency as a function of current mismatch for cell made using MVHF at a high rate. 
The study shows that reducing the bottom cell current has a deleterious effect on the initial efficiency but does not impact the stable efficiency. Other advantages of the bottom cell limited option are that the bottom cell can be made relatively thin to yield a good FF and the deposition time of the bottom cell is reduced. The overall stability depends not only on the $\mu \mathrm{c}-$ $\mathrm{Si}: \mathrm{H}$ bottom cell, but also on the quality of the a-Si:H top cell. By improving the a-Si:H top cell quality, we have improved the stability of a a-Si:H/ $\mu \mathrm{c}-\mathrm{Si}: \mathrm{H}$ double-junction cell even though the mismatch is not very high. One example is sample 11835 in Table IV. Despite a $3 \%$ degradation in $\mathrm{J}_{\mathrm{sc}}$ of the top cell, the stable active-area efficiency is $10.42 \%$.

\subsection{Uniformity studies using large area cathode at VHF frequencies}

Energy Conversion Devices, Inc. (ECD) was subcontracted for this task. Their report is summarized below.

Many years of experience with RF glow discharge technology over large areas, especially in roll-to-roll production machines, have shown that the electric field uniformity over the RF cathode is key to obtaining thickness uniformity of the a-Si:H thin films. Under this program, preliminary studies using VHF frequency have demonstrated that the electric field uniformity is even more critical at the high frequencies. We adopted a long-term approach in solving the problems associated with film thickness uniformity by carrying out a fundamental study of the electric field uniformity over the VHF cathode and techniques to improve it. We believe that if the electric field uniformity issues are addressed, we can transfer the know-how to the fabrication of large area $\mu \mathrm{c}-\mathrm{Si}: \mathrm{H}$ solar cells prepared by the high rate MVHF technique. With this as the background, the thrust under this program was to improve the electric field uniformity over the VHF cathode.

A planar cathode with a single RF back feed was modified to try to improve deposition uniformity at VHF frequencies $(60-100 \mathrm{MHz})$. The modification replaced the single feed at the back with four connections on the cathode sides at roughly 9 and 18 inches from the top of the cathode. The four feed lines were fed from one source and cut to have identical lengths so that the phase at each contact point was the same at the cathode.

Measurements were made using a wire probe with a detector, and the intensity was read out on a voltmeter. The probe was passed through a stiff plate on a frame with a $10 \times 19$ pattern of small holes covering all but the very top and bottom of the cathode. Following the measurement of RF field strength, the distance from the probe to cathode was measured, and the field strength data was normalized to compensate for probe distance variations. Figure 7 displays a photograph of the patterned plate and RF probe set up.

Measurements were made at three different frequencies: 60, 78, and $100 \mathrm{MHz}$. The power supply was set to 20 watts, the tuner managed to limit reflected power to $<0.5$ watts up to $78 \mathrm{MHz}$ and 2 watts at 100 . Figures 8 displays the electric field uniformity pattern for the 60 $\mathrm{MHz}$ case. There appears to be a consistent non-uniformity in field strength seen in these measurements. A summary of the overall uniformity for each frequency is given in Table V. One end of the cathode has higher field strength and is not symmetric, although it should be, 


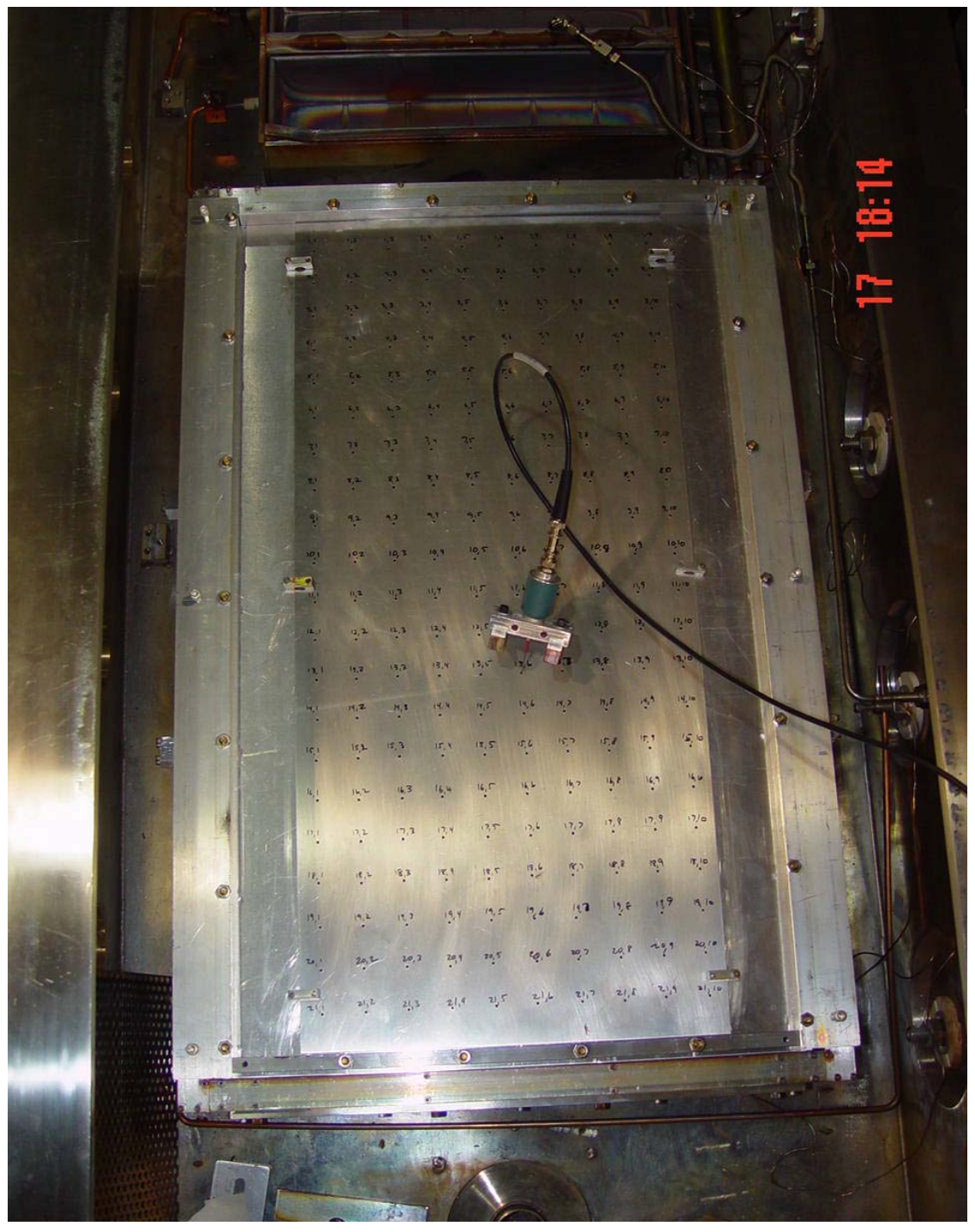

Figure 7. Uniformity measurement grid and RF probe. 


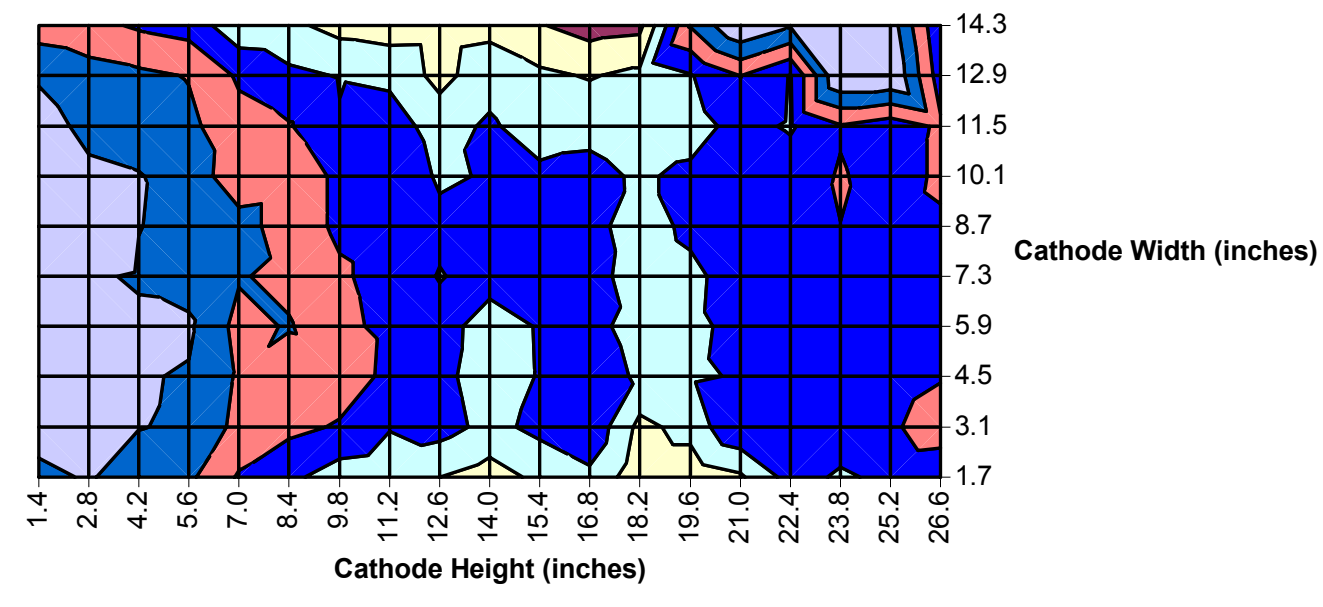

19.500

20.000

口 19.000

19.500

ㅁ18.500-

19.000

$18.000-$

18.500

ㅁ17.500-

18.000

ㅁ17.000-

17.500

ㅁ16.500-

17.000

ㅁ16.000-

16.500

Figure 8. Normalized electric field vs. cathode position @ 60MHz and $20 \mathrm{~W} / 0 \mathrm{~W}$ reflected. 
Table V. Summary of electric field uniformity over large area VHF cathode.

\begin{tabular}{|c|c|c|}
\hline FREQUENCY & $\begin{array}{c}\text { MAX. DEV. from AVE. } \\
(\%)\end{array}$ & $\begin{array}{c}\text { MIN. DEV. from AVE. } \\
(\%)\end{array}$ \\
\hline $60 \mathrm{MHz}$ & 10.8 & -9.0 \\
\hline $78 \mathrm{MHz}$ & 16.7 & -10.0 \\
\hline $100 \mathrm{MHz}$ & 16.4 & -17.3 \\
\hline
\end{tabular}

given that the feed points are symmetric. It is possible that there may be a poor contact in one or more feed lines giving rise to this and we are presently investigating. The reduction in field strength near the feed point connections is apparent as well in this data, which is expected based on previous work. Some of the irregularities are probably measurement errors in distance between probe and cathode, particularly at or near steps, holes, and screws in the cathode.

A couple of actual film deposition experiments were conducted to provide feedback. The film thickness variations have a similar structure to the field measurements. The maximum thickness is toward the top and bottom of the cathode and there is an obvious end-to-end asymmetry observed. Figure 9 shows the thickness uniformity of sample VHF046 using a partially optimized VHF cathode. The thickness variation is $+25 \%$ to $-44 \%$. This is much larger than the corresponding electric field variation. The variation in film thickness will be determined by a combination of electric field strength uniformity and gas distribution. Thus, there is a need to improve the source gas distribution as well. In a separate experiment, using a single-connection RF cathode incorporating improved gas distribution, we have obtained excellent film thickness uniformity to $\pm 7 \%$ over a $1500 \mathrm{~cm}^{2}$ area at a deposition rate of $\sim 3 \AA / \mathrm{s}$. Implementation of this design with the added rf connections should allow for uniform depositions at high rates using the $70 \mathrm{MHz}$ frequency.

\section{Summary of the Phase I achievements}

We have achieved a total-area initial efficiency of $11.47 \%$ (active-area efficiency of $12.33 \%$ ) on a-Si:H/ $\mu \mathrm{c}-\mathrm{Si}: H$ double-junction structure, where the intrinsic layer bottom cell was made in 50 minutes. On another device in which the bottom cell was made in 30 min, we achieved initial total-area efficiency of $10.58 \%$ (active-efficiency of $11.35 \%$ ). We have shown that the phenomenon of ambient degradation of both $\mu \mathrm{c}-\mathrm{Si}: \mathrm{H}$ single-junction and a-Si:H/ $\mu \mathrm{c}-\mathrm{Si}: \mathrm{H}$ double-junction cells can be attributed to impurity diffusion after deposition. Optimization of the plasma parameters led to alleviation of the ambient degradation. Appropriate current matching between the top and bottom component cells has resulted in a stable total-area efficiency of $9.7 \%$ (active-area efficiency of $10.42 \%$ ) on an a-Si:H/ $\mu \mathrm{c}-\mathrm{Si}: \mathrm{H}$ double-junction solar cell in which the deposition time for the $\mu \mathrm{c}-\mathrm{Si}: \mathrm{H}$ intrinsic layer deposition was of $30 \mathrm{~min}$. For all practical purposes, these results satisfy the goals of Phase I.

Table VI summarizes the results of a-Si:H/ $\mu \mathrm{c}-\mathrm{Si}: \mathrm{H}$ double-junction solar cells reported in the literature. During Phase I, we have catapulted to the frontrunner spot of microcrystalline silicon solar cell technology. We have accumulated a lot of experience on material optimization, material and solar cell characterization, and solar cell design for achieving high efficiency. This valuable knowledge will provide the ammunition to achieve the goals of Phase II. 


\section{VHF046}

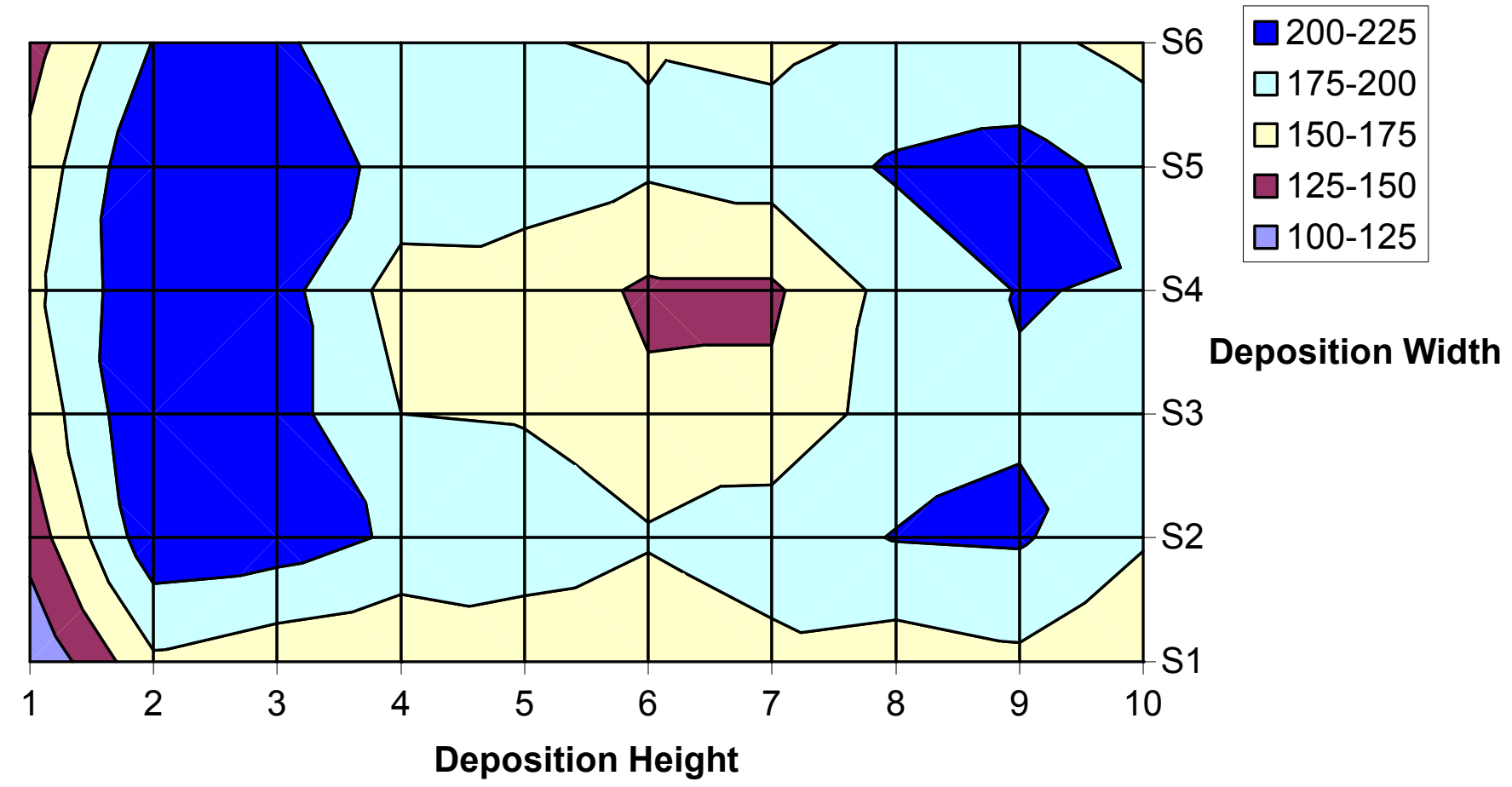

Figure 9. Measured film thickness uniformity. 
Table VI. Summary of recent data on a-Si:H/ $\mu c-S i$ double-junction cells published in the literature.

\begin{tabular}{|c|c|c|c|c|c|c|}
\hline Institution & State & $\begin{array}{c}\text { Efficiency } \\
(\%)\end{array}$ & Technique & $\begin{array}{l}\text { Rate } \\
(\AA / s)\end{array}$ & $\begin{array}{l}\text { Area } \\
\left(\mathrm{cm}^{2}\right)\end{array}$ & Reference \\
\hline \multirow[t]{2}{*}{ Kaneka, } & Initial & $\begin{array}{l}14.1 \\
11.7 \\
11.2\end{array}$ & $\mathrm{PECVD}^{1}$ & $\begin{array}{c}\mathrm{n} / \mathrm{a} \\
\mathrm{n} / \mathrm{a} \\
11\end{array}$ & $\begin{array}{c}1.0 \\
91 \times 45.5 \\
91 \times 45.5\end{array}$ & \multirow[b]{2}{*}{ [21] } \\
\hline & Stable & $12.0^{2}$ & PECVD & $\mathrm{n} / \mathrm{a}$ & 1.0 & \\
\hline \multirow[t]{2}{*}{ Canon, } & Initial & 12.75 & VHF & 10 & $\mathrm{n} / \mathrm{a}$ & \multirow[t]{2}{*}[7]{} \\
\hline & Stable & $\mathrm{n} / \mathrm{a}$ & & & & \\
\hline \multirow[t]{2}{*}{ Neuchâtel, } & Initial & $\begin{array}{l}13.0 \\
11.2\end{array}$ & $\begin{array}{l}\text { VHF } \\
\text { VHF }\end{array}$ & $\begin{array}{l}\mathrm{n} / \mathrm{a} \\
6.8\end{array}$ & $\begin{array}{l}\mathrm{n} / \mathrm{a} \\
\mathrm{n} / \mathrm{a}\end{array}$ & $\begin{array}{c}{[2]} \\
{[19]}\end{array}$ \\
\hline & Stable & 10.8 & VHF & $\mathrm{n} / \mathrm{a}$ & $\mathrm{n} / \mathrm{a}$ & [12] \\
\hline \multirow[t]{2}{*}{ Jülich, } & Initial & 11.7 & RF-HP ${ }^{3}$ & 1.2 & 1.0 & \multirow[t]{2}{*}{ [18] } \\
\hline & Stable & 10.4 & RF-HP ${ }^{3}$ & 1.2 & 1.0 & \\
\hline \multirow[t]{2}{*}{ ECD } & Initial & 10.3 & Gas-Jet & 15 & $0.25^{4}$ & \multirow[t]{2}{*}[20]{} \\
\hline & Stable & 9.6 & Gas-Jet & 15 & $0.25^{4}$ & \\
\hline \multirow[t]{4}{*}{ United Solar } & Initial & 12.33 & VHF & 5 & $0.25^{4}$ & \multirow{2}{*}{$\begin{array}{l}\text { Phase I } \\
\text { results }\end{array}$} \\
\hline & Stable & 10.42 & VHF & 5 & $0.25^{4}$ & \\
\hline & Initial & 13.0 & $\mathrm{RF}$ & 1 & $0.25^{4}$ & \multirow[t]{2}{*}[15]{} \\
\hline & Stable & 11.24 & $\mathrm{RF}$ & 1 & $0.25^{4}$ & \\
\hline
\end{tabular}

1. No detail information about excitation frequency is available.

2. a-Si:H/ $\mu \mathrm{c}-\mathrm{Si}: \mathrm{H} / \mu \mathrm{c}-\mathrm{Si}: \mathrm{H}$ triple-junction cell.

3. HP means high pressure.

4. Active-area. The total area is $0.268 \mathrm{~cm}^{2}$.

\section{References}

1. Subhendu Guha, Mat. Res. Soc. Symp. Proc. 808, 521 (2004).

2. J. Meier, R. Fluckiger, H. Keppner, and A. Shah, Appl. Phys. Lett. 65, 860 (1994).

3. K. Yamamoto, A. Nakajima, M. Yoshimi, T. Sawada, S. Fukuda, K. Hayashi, T. Suezaki, M. Ichikawa, Y. Koi, M. Goto, H. Takata, and Y. Tawada, Proc. of $29^{\text {th }}$ IEEE Photovoltaic Specialists Conference, New Orleans, (2002), p.1110.

4. J. Yang, A. Banerjee, and S. Guha, Appl. Phys. Lett. 70, 2975 (1997).

5. A. Banerjee, J. Yang, and S. Guha, Mat. Res. Soc. Symp. Proc. 557, 743 (1999).

6. J. Meier, P. Torres, R. Platz, S. Dubail, U. Kroll, J. A. Anna Selvan, N. Pellaton Vaucher, Ch. Hof, D. Fischer, H. Keppner, A. Shah, K.-D. Ufert, P. Giannoules, and J. Koehler, Mat. Res. Symp. Proc. 420, 3 (1996).

7. K. Ogawa, K. Saito, M. Sano, A. Sakai, and K. Matsuda, Technical Digest of the International PVSEC-12, Jeju, Korea, (2001), p.343.

8. Y. Nasuno, M. Kondo, and A. Matsuda, Mat. Res. Symp. Proc. 664, A15.5 (2001).

9. Y. Nasuno, M. Kondo, and A. Matsuda, Technical Digest of the International PVSEC-12, Jeju, Korea, (2001), p.791. 
10. O. Vetterl, R. Carius, L. Houben, C. Scholten, M. Luysberg, A. Lambertz, F. Finger, and H. Wagner, Mat. Res. Symp. Proc. 609, A15.2.1 (2000).

11. Y. Nasuno, M. Kondo, and A. Matsuda, Conf. Record of $28^{\text {th }}$ IEEE Photovoltaic Specialists Conference, Anchorage, Alaska, (2000), p. 142.

12. A. V. Shah, J. Meier, E. Vallat-Sauvain, N. Wyrsch, U. Kroll, C. Droz, U. Graf, Solar Energy Materials and Solar Cells 78, 469 (2003) in press

13. J. Yang, B. Yan, J. Smeets, and S. Guha, Mat. Res. Symp. Proc. 664, A11.3.1 (1993).

14. W.A. Turner and G. Lucovsky, Mat. Res. Symp. Proc. 297, 521 (1993).

15. B. Yan, K. Lord, J. Yang, S. Guha, J. Smeets, J.-M. Jacquet, Mat. Res. Soc. Symp. Proc. 715, 629 (2002); B. Yan, G. Yue, K. Lord, J. Yang, and S. Guha, Mat. Res. Soc. Symp. 762, (2003).

16. M.B. Schubert, R. Brüggemann, G. Bilger, and A. Hierzenberger, Proc. of $2^{\text {nd }}$ World Conf. and Exhibition on Photovoltaic Solar Energy Conversion, Vienna, Austria (1998), p. 834.

17. M. Goerlitzer, P. Torres, N. Beck, N. Wyrsch, H. Keppner, J. Pohl, and A. Shah, J. NonCrystalline Solids, 227-230, 996 (1998).

18. T. Repmann, W. Appenzeller, T. Roschek, B. Rech, O. Kluth, J. Muller, W. Psyk, R. Geyer, P. Lechner, Proc. $17^{\text {th }}$ European Photovoltaic Solar Energy Conference and Exhibition, (Germany 2002), p. 2836.

19. L. Feitknecht, O. Kluth, Y. Ziegler, X. Niquille, P. Torres, J. Meier, N. Wyrsch, and A. Shah, Technical Digest of the International PVSEC-11, Sapporo, Japan, (1999), p.239.

20. S.J. Jones, T. Liu, R. Crucet, R. Capangpangan, J. Steel, and M. Isu, National Center for Photovoltaics Program Review Meeting, Colorado, (2001).

21. K. Yamamoto, M. Yoshimi, Y. Tawada, Y. Okamoto, and A. Nakajima, Technical Digest of the International PVSEC-11, Sapporo, Japan, (1999), p.225. 